\title{
Dietary structural to nonfiber carbohydrate concentration during the transition period in grazing dairy cows
}

\author{
J. R. Roche, ${ }^{1}$ J. K. Kay, C. V. C. Phyn, S. Meier, J. M. Lee, and C. R. Burke \\ DairyNZ Limited, Private Bag 3221, Hamilton, New Zealand
}

\begin{abstract}
A study was conducted to evaluate the potential effects of altering the proportion of dietary structural carbohydrate (SC) relative to nonfiber carbohydrate (NFC) pre- and postpartum on milk production and the circulating concentrations of hormones and metabolites. Dietary treatments were arranged as a $2 \times 2$ factorial, with 68 multiparous cows assigned to isoenergetic diets [114 MJ of metabolizable energy (ME)/ cow per d] precalving; diets were either fresh pasture and pasture silage (PreP) or pasture and pasture silage supplemented with $3 \mathrm{~kg}$ dry matter (DM)/cow per d of a corn- and barley-based concentrate for 36 d prepartum (PreC). Final treatments were 13 or $32 \%$ DM NFC, respectively. After calving, cows within each prepartum diet were assigned to isoenergetic diets (179 MJ of ME/cow per d) differing in their SC and NFC content. Postcalving diets were either fresh pasture and pasture silage (PostP) or pasture and pasture silage supplemented with $5 \mathrm{~kg} \mathrm{DM} /$ cow per d of a corn- and barley-based concentrate (PostC) until $35 \mathrm{~d}$ in milk. Final treatments were 18 and $38 \%$ DM NFC, respectively. Relative to day of calving (d 0), blood samples were collected at least weekly from d -28 to d 35 . During the prepartum period, PreC cows had lower plasma urea, albumin, insulin-like growth factor-I, and Ca concentrations, but greater nonesterified fatty acid and $\mathrm{Mg}$ concentrations. There were no evident effects of prepartum diet on body weight or body condition score, milk yield, or milk composition. During the postpartum period, PostC cows had lower concentrations of plasma urea, $\beta$-hydroxybutyrate, and $\mathrm{Ca}$, but greater concentrations of nonesterified fatty acids, glucose, insulin-like growth factor-I, and Mg. Postpartum metabolic differences in PostC cows were associated with increased milk protein production and reduced milk fat (yield and \%). Results do not support a periparturient metabolic benefit to altering the SC to NFC ratio precalving, but imply an altered rumen fermentation, gluconeogenesis, and milk
\end{abstract}

Received October 29, 2009.

Accepted April 14, 2010.

${ }^{1}$ Corresponding author: john.roche@dairynz.co.nz composition when dietary $\mathrm{SC}$ to $\mathrm{NFC}$ ratio is altered postcalving.

Key words: dairy cow, transition diet, metabolic hormone, milk production

\section{INTRODUCTION}

The period of transition between late gestation and early lactation presents a significant metabolic challenge to the dairy cow (Bell, 1995; Grummer, 1995), with claims that it determines the success or failure of the cow in the upcoming lactation (Drackley, 1999). Consistent with this view, Godden et al. (2003) reported that $25 \%$ of cows culled in dairy herds in Minnesota left the herd in the first 60 DIM. In recognition of the importance of this transition, the management and associated physiology of the periparturient cow has been a significant research focal point for the last 2 decades (Overton and Waldron, 2004).

The dramatic change in nutrient demands and sinks from pre- to postpartum is what makes the transition period such a metabolic challenge. During late gestation, the fetal metabolic rate is approximately twice that of the dam (Reynolds et al., 1986; Bell, 1995) and the requirements for pregnancy (i.e., maintenance of the gravid uterus) are approximately equal to that of cow maintenance (Roche et al., 2005). In addition to this increasing fetal drain on energy, mammary uptake of glucose and acetate increase 4- and 2-fold, respectively, in the $4 \mathrm{~d}$ preceding parturition (Bell, 1995). Such rapid changes in energy requirements require almost immediate increases in hepatic gluconeogenesis and a reduction in the peripheral use of these compounds and are generally facilitated by mammalian homeorhetic adaptations. As selection for milk production has intensified, the requirements for lactogenesis and galactopoiesis have further increased. Bell (1995) estimated that mammary uptake of glucose, amino acids, and fatty acids during the weeks prepartum for a cow destined to produce 30 $\mathrm{kg}$ of milk/d should be approximately $1.8,1.4$, and 1.2 $\mathrm{kg} / \mathrm{d}$, respectively. In comparison, fetal requirements during this period were estimated to be $0.18,0.28$, and $0.07 \mathrm{~kg} / \mathrm{d}$, respectively.

A logical extension of these data is that the periparturient cow has a significantly greater requirement 
for glucose and would be aided during transition by the provision of gluconeogenic precursors. In a review of recent research in transition cow nutrition, Overton and Waldron (2004) reported that an increase in NFC prepartum consistently increased DMI prepartum and generally had positive effects on peripartum metabolism and milk yield postpartum. However, they also noted that these studies were confounded by differences in diet $\mathrm{NE}_{\mathrm{L}}$ content and cow $\mathrm{NE}_{\mathrm{L}}$ intake, variables likely to affect peripartum plasma metabolite and hormone concentrations, and milk production (Douglas et al., 1998; Holcomb et al., 2001; Agenäs et al., 2003; Roche et al., 2005; Roche, 2007). Recognizing the confounding effects of energy intake in previous studies, Smith et al. (2005) formulated isoenergetic diets that differed only in the NFC content of the TMR. They reported no effect of altering the carbohydrate composition of the prepartum diet on pre- or postpartum DMI or milk production. However, the dietary NFC treatment differences were small with their high and low NFC diet containing 40 and $34 \% \mathrm{DM}$ as NFC, respectively. Furthermore, in all of these studies, cows were fed significant quantities of NFC postpartum, and some of the reported benefits may be a result of improved acclimation of the rumen microorganisms and, possibly, the epithelium prepartum (Dirksen et al., 1985, 1997), although the latter is unlikely when the base forage is of higher quality (Andersen et al., 1999; Reynolds et al., 2004).

Pasture-based diets tend to contain moderate concentrations of NFC (11 to 15\%; Roche et al., 2009a), with the majority of energy substrates for microbial fermentation provided by structural carbohydrates (SC). There is, therefore, a possible shortage of gluconeogenic precursors prepartum and in the weeks immediately postpartum, when galactopoiesis is an increasing drain on circulating glucose. The objective of this experiment was to determine the effect of altering dietary $\mathrm{SC}$ to NFC content prepartum on milk production, and whether any effect is dependent on postpartum diet composition.

\section{MATERIALS AND METHODS}

This study was conducted at the DairyNZ Lye Farm, Hamilton, New Zealand $\left(37^{\circ} 46^{\prime} \mathrm{S}, 175^{\circ} 18^{\prime} \mathrm{S}\right)$ between July and September 2005. All procedures had prior approval of the Ruakura Animal Ethics Committee, New Zealand.

\section{Experimental Design and Treatments}

At $36 \pm 8.7 \mathrm{~d}$ (mean $\pm \mathrm{SD}$ ) prepartum, 68 multiparous Holstein-Friesian and Holstein-Friesian $\times$ Jersey crossbred cows due to calve over a 21-d period were randomly allocated to 1 of 2 prepartum diets $(\mathrm{n}=34)$. Treatments were balanced for milk production during early lactation in the previous year $(20.5 \pm 4.4 \mathrm{~kg}$ of milk/cow per d; $0.96 \pm 0.20 \mathrm{~kg}$ of milk fat/cow per d; $0.70 \pm 0.15 \mathrm{~kg}$ of milk protein/cow per d), BW (529 \pm $60 \mathrm{~kg})$, BCS (4.75 \pm 0.7 ; 10-point scale; Roche et al., $2004)$, age $(4.3 \pm 1.3 \mathrm{yr})$, and predicted calving date.

Prepartum dietary treatments consisted of feeding cows either pasture and pasture silage $(\mathbf{P r e P})$ or an isoenergetic comparison receiving $3 \mathrm{~kg} \mathrm{DM} /$ cow per $\mathrm{d}$ of a concentrate pellet (32\% crushed barley, $60 \%$ crushed corn, $2 \%$ wheat middlings, $6 \%$ molasses) in place of an equivalent amount of energy from pasture and pasture silage (PreC). Treatment diets were isoenergetic and offered to supply cows with $110 \%$ of their calculated prepartum energy requirements (96 MJ of ME/cow per d; Roche et al., 2005).

At calving, cows in each prepartum treatment were randomly allocated to 1 of 2 postpartum dietary treatments $(\mathrm{n}=34)$ in a $2 \times 2$ factorial arrangement and offered either pasture and pasture silage (PostP) or an isoenergetic comparison receiving $5 \mathrm{~kg} \mathrm{DM} /$ cow per d of the same concentrate (PostC). The $5 \mathrm{~kg}$ of DM concentrates were introduced gradually over a 3 -d period and offered in 2 equal portions at p.m. and a.m. milkings. Energy allocation was based on the PostP group being unrestricted (on average consuming 179 MJ of $\mathrm{ME} /$ cow per d). Individual treatments included PrePPostP, PreC-PostP, PreP-PostC, and PreC-PostC ( $\mathrm{n}=$ 17 per treatment cell). Postpartum feeding treatments continued for $35 \mathrm{~d}$.

\section{Grazing Management}

Cows were rotationally grazed similar to the method described by Roche et al. (2005). Briefly, cows had access to 52 paddocks (defined grazing area) of 1 ha/ paddock, and these paddocks were grazed in rotation. As a result, cows had access to a fresh allocation of pasture twice daily and only returned to the same area when a minimum of 2 leaves had appeared on the majority $(>66 \%)$ of perennial ryegrass (Lolium perenne L.) tillers. The pasture offered prepartum consisted of $77( \pm 8.2) \%$ perennial ryegrass leaf, 7 $( \pm 2.8) \%$ perennial ryegrass stem, $7( \pm 5.8) \%$ white clover (Trifolium repens), $1.7( \pm 2.9) \%$ weeds and other grasses (Dactylis glomerata, Holcus lanatus, and some Poa species $)$, and $8( \pm 2.2) \%$ dead material on a DM basis. Postpartum, the sward consisted of 82 $( \pm 6.6) \%$ perennial ryegrass leaf, $5( \pm 4.8) \%$ perennial ryegrass stem, $5( \pm 4.5) \%$ white clover, $1( \pm 1.9) \%$ weeds and other grasses, and $6( \pm 3.6) \%$ dead material on a DM basis. The nutritive characteristics and 
Table 1. Mean (SD in parentheses) DMI and nutrient composition (\% of DM, unless otherwise stated) of isoenergetic diets differing in the ratio of structural to NFC content offered pre- and postpartum in a $2 \times 2$ factorial arrangement

\begin{tabular}{|c|c|c|c|c|}
\hline \multirow[b]{2}{*}{ Item } & \multicolumn{4}{|c|}{ Main treatment ${ }^{1}$} \\
\hline & PreC & PreP & PostC & PostP \\
\hline DMI, kg/cow per d & $9.8(1.06)$ & $10.3(1.11)$ & $14.1(1.48)$ & $15.2(2.45)$ \\
\hline NFC & $31.8(3.20)$ & $13.2(2.21)$ & $38.1(4.00)$ & $17.8(4.25)$ \\
\hline $\mathrm{CP}$ & $16.8(0.94)$ & $22.1(1.52)$ & $17.0(1.57)$ & $20.1(1.18)$ \\
\hline NDF & $39.3(2.01)$ & $52.1(1.55)$ & $33.3(2.59)$ & $47.4(3.83)$ \\
\hline $\mathrm{ADF}$ & $21.1(1.01)$ & $27.9(1.41)$ & $16.7(1.23)$ & $24.7(2.48)$ \\
\hline Lipid & $3.8(0.19)$ & $4.2(0.16)$ & $3.8(0.17)$ & $4.4(0.16)$ \\
\hline Ash & $8.2(0.47)$ & $10.3(0.28)$ & $7.8(0.49)$ & $10.3(0.55)$ \\
\hline $\mathrm{ME}, \mathrm{MJ} / \mathrm{kg}$ of DM & $11.8(0.31)$ & $11.2(0.42)$ & $12.5(0.35)$ & $11.7(0.78)$ \\
\hline
\end{tabular}

${ }^{1}$ Prepartum diets (114 MJ of ME consumed/cow per d) were pasture and pasture silage (PreP) or pasture and pasture silage supplemented with $3 \mathrm{~kg} \mathrm{DM} /$ cow per d of barley-corn grain concentrate (PreC). Postpartum diets (179 MJ of ME consumed/cow per d) were pasture and pasture silage (PostP) or pasture and pasture silage supplemented with $5 \mathrm{~kg} \mathrm{DM} /$ cow per d of barley-corn grain concentrate (PostC).

mineral concentrations of the diets offered pre- and postpartum are presented in Table 1.

Pre- and postpartum, the treatment groups were grazed within the same paddock and separated by double strands of electric fence to control pasture allowances. Back-grazing beyond the current day's allocation was prevented by using electric fences, and the cows had access to water in their respective treatment areas. Because cows were grazed within the same paddock, pregrazing pasture height and mass did not differ between treatments. Average pregrazing pasture height was $10.5( \pm 1.23) \mathrm{cm}$ prepartum, and pregrazing pasture mass averaged $3,750( \pm 309.7) \mathrm{kg}$ of DM/ ha. Postpartum, average pregrazing pasture height and mass were $11.2( \pm 2.39) \mathrm{cm}$ and $3,840( \pm 408.4) \mathrm{kg}$ of $\mathrm{DM} /$ ha, respectively.

To achieve isoenergetic diets, different pasture allowances and hence different sized daily grazing areas were allotted to each treatment group within the same paddock. Area/group changed with decreasing cow numbers precalving (i.e., as cows calved) and increasing cow numbers postcalving (i.e., as calved cows entered the milking herd). Area allocation $\left(\mathrm{m}^{2} / \mathrm{cow}\right)$ was calculated by multiplying pregrazing pasture mass per square meter by the desired allowance per cow. Daily group allocation was then calculated by multiplying the area allocation by the number of cows remaining in the prepartum group. Grazing areas averaged $22.6( \pm 10.88)$, $35.6( \pm 9.47), 35( \pm 14.0)$, and $72( \pm 38.5) \mathrm{m}^{2}$ for PreC, PreP, PostC, and PostP groups, respectively.

\section{Pasture Measurements}

Compressed pasture height was measured pre- and postgrazing using a Rising Plate Meter installed with an electronic counter (Farmworks, Palmerston North,
New Zealand). On $4 \mathrm{~d}$ of each week prepartum, pre- and postgrazing pasture mass was calculated by cutting and drying samples representative of available and residual DM. Briefly, pasture samples from each treatment group were cut to ground level within rectangular quadrants $\left(0.125 \mathrm{~m}^{2}\right)$ placed randomly within pasture allocations to be grazed the following day and, for residual DM, those grazed during the previous $24 \mathrm{~h}$. Pasture samples were washed to remove soil contamination and dried at $100^{\circ} \mathrm{C}$ to constant weight (for approximately $72 \mathrm{~h}$ ). Resultant DM yields $/ 0.25 \mathrm{~m}^{2}$ were multiplied by 80,000 to give DM yield/ha pre- and postgrazing. Compressed pasture heights were measured inside each $0.125-\mathrm{m}^{2}$ quadrant before cutting. These data were used to develop a regression equation relating pasture height to pasture mass.

$$
\begin{gathered}
\text { Pasture mass }(\mathrm{kg} \text { of } \mathrm{DM} / \mathrm{ha})= \\
284.6 \times \text { pasture height }(\mathrm{cm})+646.8 ; \\
P<0.001: \mathrm{r}^{2}=0.79 ; \mathrm{n}=552 .
\end{gathered}
$$

Prepartum, 200 pasture height measurements were made in pastures to be grazed, the pasture mass estimated and this value used to allocate desired grazing area. Each day before grazing, 100 pasture height measurements were made in each treatment area to ensure pasture allocation was correct.

Representative samples of pasture were collected daily by "plucking" pasture to grazing height from paddocks due to be grazed. Samples were bulked on a 2-weekly basis, and duplicate samples were dried at either $100^{\circ} \mathrm{C}$ for DM analysis or $60^{\circ} \mathrm{C}$ for analysis of nutrient composition. All samples were dried at $60^{\circ} \mathrm{C}$ for $48 \mathrm{~h}$, ground to pass through a $1.0-\mathrm{mm}$ sieve (Christy Lab Mill, 
Suffolk, UK) and analyzed for CP, NDF, ADF, NFC, fat, ash, and OM digestibility by near infrared spectroscopy (Corson et al., 1999). The ME content was derived directly from predicted OM digestibility, based on an in vitro cellulase digestibility assay (Roughan and Holland, 1977; Dowman and Collins, 1982), which had been calibrated against in vivo standards (Corson et al., 1999).

\section{Animal Measurements}

DMI. Mean group pasture DMI was calculated as the product of the difference between the pre- and postgrazing pasture mass and area grazed daily, as outlined by Roche et al. (1996). Supplement offered and refused was measured daily. The product of daily DMI and diet energy density was used to determine daily energy intake.

Milk and $\boldsymbol{B} \boldsymbol{W}$. Individual milk yields were recorded daily (GEA, Oelde, Germany). Fat, CP, and lactose concentrations in milk were determined by Milkoscan (Foss Electric, Hillerød, Denmark) on individual p.m. and a.m. aliquot samples collected on $2 \mathrm{~d} / \mathrm{wk}$ for the first $5 \mathrm{wk}$ of lactation. Milk component data were verified by reference techniques for a subset of milk samples (milk fat by Röse-Gottlieb method, IDF, 1987; CP by Kjeldahl techniques, Barbano et al., 1991). Prepartum BW and BCS were determined every week at approximately $0900 \mathrm{~h}$. Postpartum BW and BCS were measured weekly following the a.m. milking. Body condition score was assessed pre- and postpartum on a 10-point scale, where 1 is emaciated and 10 is obese (Roche et al., 2004). These scores can be converted to the 5-point scale of Wildman et al. (1982) using the regression equation generated by Roche et al. (2004; 5 -point BCS $=1.5+0.32 \times 10$-point BCS).

Blood. One evacuated blood tube containing a sodium heparin pellet (100 IU of sodium heparin $/ \mathrm{mL}$ of blood) to prevent coagulation was collected from each cow by coccygeal venipuncture before treatment allocation and weekly thereafter. Additional blood samples were collected at calving (d 0), and on $\mathrm{d} 1,2,3$, and 4 postpartum. Plasma was harvested $(1,120 \times g, 10$ min, $4^{\circ} \mathrm{C}$ ) and analyzed for NEFA, BHBA, glucose, urea, albumin, growth hormone (GH), IGF-1, insulin, $\mathrm{Ca}$, and Mg. Determinations of NEFA (mmol/L; colorimetric method using a commercial kit from Wako, Osaka, Japan), BHBA (mmol/L; BHBA dehydrogenase assay based on formation of acetoacetate and NADH after addition of NAD), glucose (mmol/L; hexokinase method based on formation of NADPH), albumin (g/L; citrate buffer reagent), urea $(\mathrm{mmol} / \mathrm{L}$; urease hydrolysis method), $\mathrm{Ca}$ (mmol/L; o-cresolphthalein complexone method), and $\mathrm{Mg}$ (mmol/L; xylidyl blue reaction) were performed on a Hitachi 717 analyzer (Roche, Basel, Switzerland) at $30^{\circ} \mathrm{C}$ by Gribbles Veterinary Pathology Ltd. (Hamilton, New Zealand). The inter- and intraassay CV were $<2 \%$ for all assays. Growth hormone (Downing et al., 1995), IGF-1 (Gluckman et al., 1983), and insulin (Hales and Randle, 1963) were measured in duplicate by double-antibody RIA with inter- and intraassay $\mathrm{CV}<6 \%$.

\section{Statistical Analyses}

Summary data were analyzed using linear models and generalized linear models (v. 11.1, VSN International, Hemel Hempstead, UK; Payne et al., 2008). The model included pre- and postpartum diets and the interaction as fixed effects, with cow as a random effect. Repeated measures of milk production and blood hormone and metabolite data through time were modeled using REML-spline models within the linear mixed model framework as described in Verbyla et al. (1999). Interactions with time were explored further using linear models at each time point.

\section{RESULTS}

\section{Milk Production, BCS, and BW}

Prepartum diet did not affect milk yield or milk composition during the first 35 DIM and, with the exception of lactose concentration $(4.674,4.755,4.755$, and $4.684 \%$ in PreC-PostC, PreC-PostP, PreP-PostC, and PreP-PostP, respectively; $P<0.01$ ), there were no interactions between pre- and postpartum diets (Table 2).

Postpartum diet did not affect the yield of FCM or ECM, although milk yield $(\mathrm{kg} / \mathrm{cow}$ per $\mathrm{d})$ tended $(P$ $=0.07)$ to be greater in PostC cows during the first 35 DIM (Table 2). Cows in the PostC treatment had a lower milk fat percentage and yield, but increased milk protein yield and a tendency for increased milk lactose yield compared with PostP cows (Table 2). The effects of postpartum diet on milk and ECM yield, as well as fat and protein percentage, were consistent through 35 DIM (Figure 1).

Body weight and BCS change were not affected by the pre- or postpartum diet (Figure 2). Cows maintained BCS prepartum and lost 0.08 to 0.10 BCS units/cow per wk (1 to 10 scale; Roche et al., 2004) postpartum, irrespective of diet.

\section{Plasma Metabolites and Hormones}

Prepartum Diet. The effects of prepartum diet on plasma metabolite and hormone concentrations are 
Table 2. Mean milk production characteristics during the first 35 DIM in cows offered pre- (PreC and PreP) and postpartum isoenergetic diets (PostC and PostP) differing in the ratio of structural to nonfiber carbohydrate content

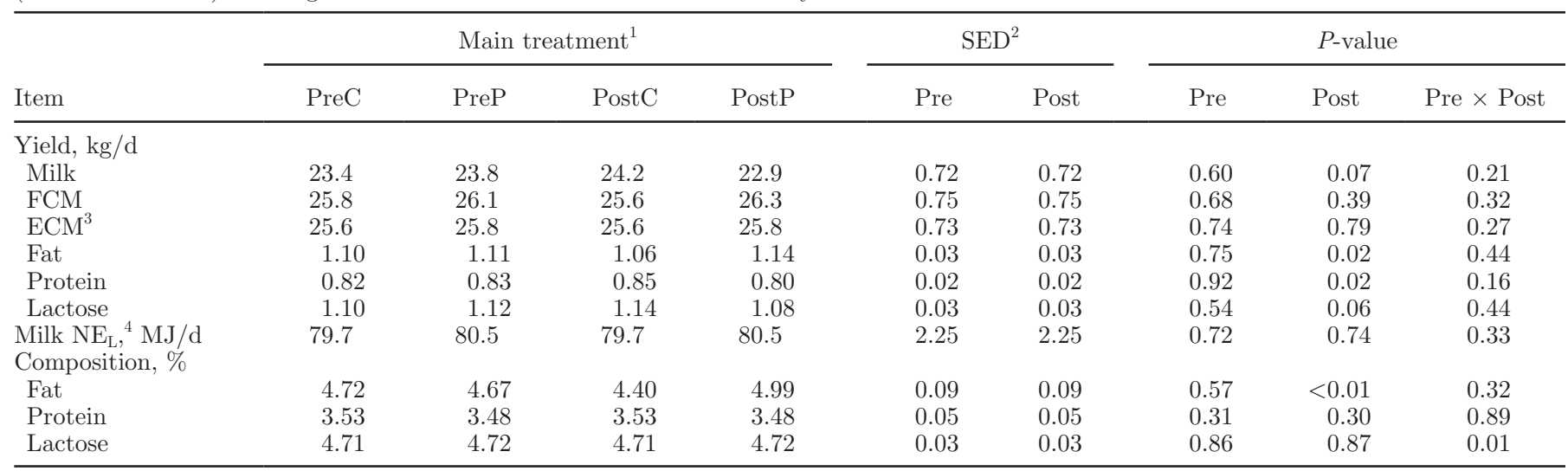

${ }^{1}$ Prepartum diets (114 MJ of ME consumed/cow per d) were pasture and pasture silage (PreP) or pasture and pasture silage supplemented with $3 \mathrm{~kg} \mathrm{DM} /$ cow per d of barley-corn grain concentrate (PreC). Postpartum diets (179 MJ of ME consumed/cow per d) were pasture and pasture silage (PostP) or pasture and pasture silage supplemented with $5 \mathrm{~kg} \mathrm{DM} / \mathrm{cow}$ per d of barley-corn grain concentrate (PostC).

${ }^{2}$ Standard error of the difference.

${ }^{3} \mathrm{ECM}$ calculated as $\mathrm{kg} / \mathrm{cow}$ per $\mathrm{d}=\mathrm{kg}$ of milk $\times(383 \times$ fat $\%+242 \times$ protein $\%+783.2) / 3,140$ (Tyrrell and Reid, 1965).

${ }^{4} \mathrm{NE}_{\mathrm{L}} ; \mathrm{MJ} /$ cow per $\mathrm{d}=[(0.0929 \times$ fat $\%)+(0.0547 \times \mathrm{CP} \%)+(0.0395 \times$ lactose $\%)] \times 4.186 \mathrm{MJ} / \mathrm{Mcal} \times \mathrm{kg}$ of milk $/$ cow per $\mathrm{d}$.

presented in Figure 3 and Tables 3, 4, and 5. Cows on the PreC diet had increased plasma NEFA $(P<$ 0.001; Figure 3), and reduced plasma albumin and urea concentrations (Table 3). The effect of the PreC diet on blood urea and albumin remained evident for 7 and $14 \mathrm{~d}$ postpartum, respectively (Table 3 ). In comparison, prepartum concentrations of glucose (Table 3 ) and BHBA (Figure 3) were unaffected by prepartum diet.

Prepartum plasma GH concentrations were not affected by prepartum diet, but IGF-1 and insulin were greater in PreP cows (Table 4). For the first $7 \mathrm{~d}$ after calving, GH was almost 50\% greater in plasma in PreP cows compared with that in PreC cows. Postpartum IGF-1 concentrations were not affected by prepartum diet, but insulin was greater in PreC cows during the first $2 \mathrm{~d}$ postpartum.

Plasma $\mathrm{Mg}$ was greater in PreC cows than in PreP cows during the prepartum period, but prepartum diet did not affect postpartum $\mathrm{Mg}$ concentrations (Table 5). In comparison, the PreC diet reduced plasma Ca prepartum; this effect was reversed during the first week postpartum, when plasma Ca was greater in PreC cows (Table 5).

Postpartum Diet. Plasma urea was reduced in PostC cows throughout the postpartum period (Table $3)$. There were small and inconsistent effects of postpartum diet on plasma albumin. Plasma NEFA was not affected by postpartum diet until $21 \mathrm{~d}$, after which PostC cows had greater plasma NEFA compared with PostP cows $(P<0.01 ;$ Figure 3$)$. In comparison, plasma BHBA was greater $(P<0.001)$ in PostP cows from $\mathrm{d}$ 4 to 35 (Figure 3). Plasma glucose concentrations were greater in PostC cows from d 7 to 28 (Table 3). Plasma $\mathrm{GH}$ and insulin were largely unaffected by postpartum diet, but IGF-1 was greater in PostC cows from d 14 to 35 (Table 4). Plasma $\mathrm{Mg}$ was greater, whereas plasma $\mathrm{Ca}$ was reduced, in PostC cows during the first 7 or 14 d postpartum, respectively, compared with PostP cows (Table 5).

There were no consistently detectable interactions between pre- and postpartum diets on plasma metabolites (Table 3), hormones (Table 4), or minerals (Table 5) measured in this study.

\section{DISCUSSION}

Glucose requirements during the transition through parturition and lactogenesis provide a theoretical justification for increasing dietary NFC content during the lead-up to calving, to increase milk production and aid the metabolic transition of the cow through calving and lactogenesis (Reynolds et al., 2004). However, in the majority of studies where this hypothesis was tested, carbohydrate type and energy intake have been invariably confounded. In addition, the difference in NFC content compared has been relatively small, and there has been no accounting for postpartum diet and any possible interactions that may occur between pre- and postpartum ration. A further limitation of the global data set is the lack of available information for pasturebased systems, where the diet generally contains low to moderate dietary NFC concentrations (Roche et al., 2009a). Results generated here indicate only a transient effect of prepartum NFC content on plasma metabolites 

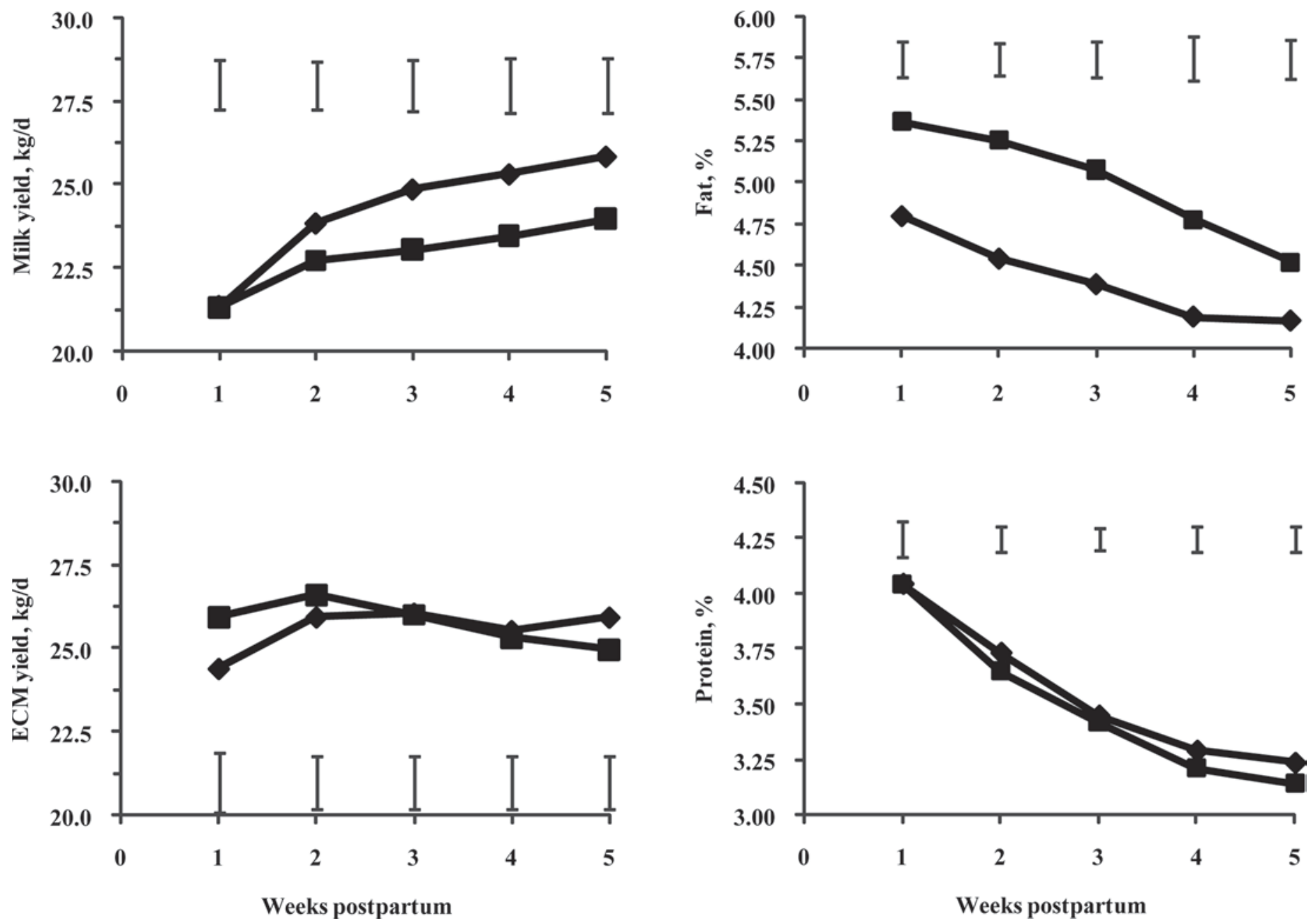

Figure 1. Daily milk yield, ECM, and fat and protein percentages of cows offered an isoenergetic postpartum diet (179 MJ of ME/cow per d) differing in the ratio of structural to NFC content. Diets consisted of pasture and pasture silage (PostP, $\mathbf{a})$ or pasture and pasture silage supplemented with $5 \mathrm{~kg} \mathrm{DM} /$ cow per d of a barley-corn grain concentrate (PostC, $\bullet$ ). ECM was calculated as $\mathrm{kg} / \mathrm{cow}$ per d $=\mathrm{kg}$ of milk $\times(383$ $\times$ fat $\%+242 \times$ protein $\%+783.2) / 3,140($ Tyrrell and Reid, 1965). Vertical bars represent twice the standard error of the difference.

and hormones, and no effect on milk production. In comparison, postpartum dietary NFC content affected milk composition, as well as circulating concentrations of metabolites and hormones of physiological importance.

\section{Milk Production}

Prepartum carbohydrate type failed to affect milk yield or composition in the current study. These findings are not consistent with those of Keady et al. (2001) or McNamara et al. (2003), both of whom supplemented a pasture silage-based diet with concentrates. However, these previous experiments involved altering the amount of energy consumed by the cows prepartum, as well as the type of carbohydrate supplied. Prepartum energy intake is positively associated with milk production postpartum, probably through greater calving BCS (Overton and Waldron, 2004; Roche et al., 2005), making it impossible to distinguish between the adequacy of the diet from an energy intake or NFC content perspective in these experiments.

Overton and Waldron (2004) drew attention to this lack of clarity in previous research where cows were fed TMR, and Smith et al. (2005) investigated the effect of prepartum diet NFC content in an isoenergetic comparison. They also reported no effect of diet NFC on either postpartum DMI or milk production, when cows consumed the same amount of energy prepartum. However, the diets imposed by Smith et al. (2005) differed in NFC content by only 7 percentage points. The content of NFC in the diets compared within the current experiment differed by 17 percentage points (31.8 and 13.2 for PreC and PreP, respectively), and 

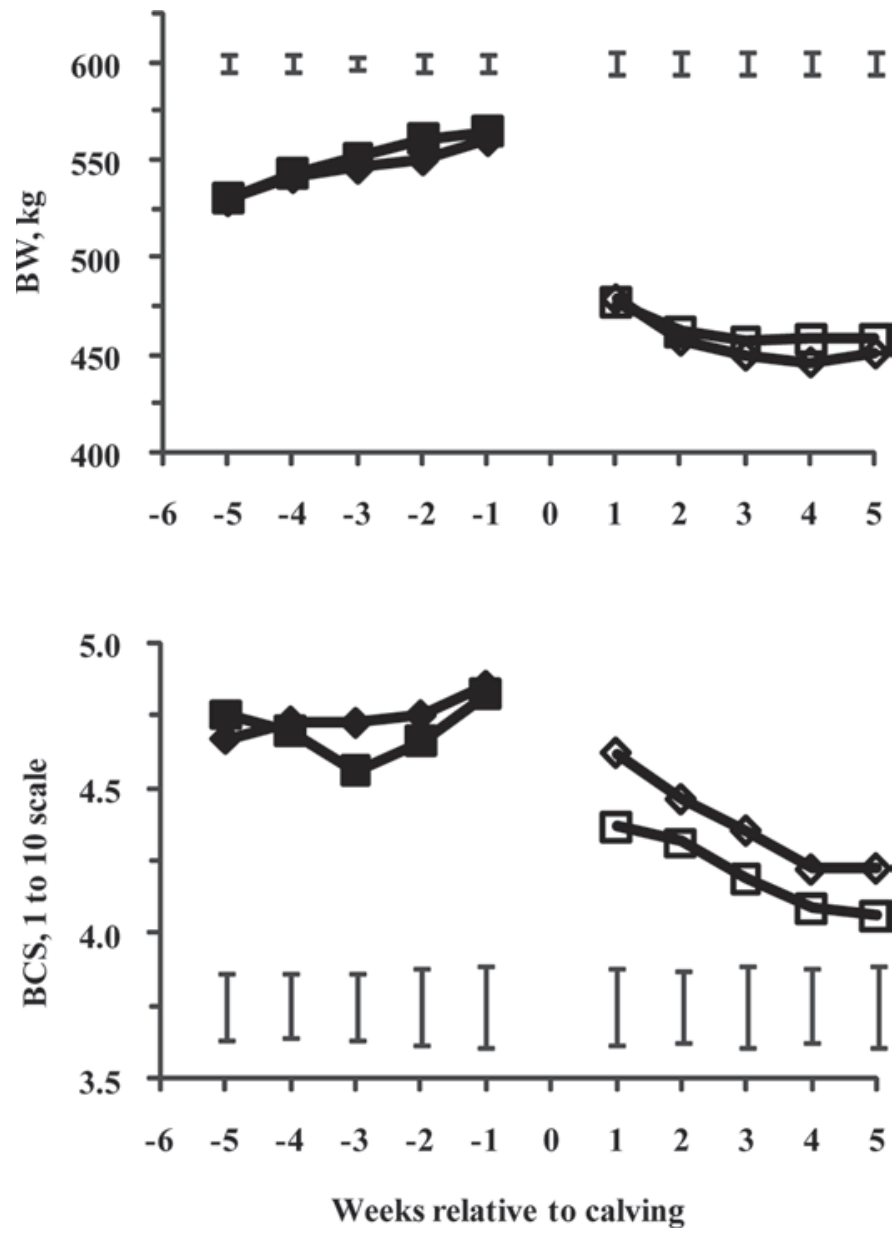

Figure 2. Body weight and BCS (1-10 scale) of cows offered isoenergetic diets differing in NFC concentration pre- and postpartum. Treatment diets contained either low (pasture and pasture silage; $\square$, - ) or high (pasture, pasture silage, and a grain-based concentrate $\diamond$, - NFC. Vertical bars represent twice the standard error of the difference.

the PreC diet was comparable with the low NFC diet offered by Smith et al. (2005). These data, therefore, imply that it is energy intake prepartum that is important for milk production postpartum, not the type of energy per se, and that there is little if any benefit to replacing fermentable SC with NFC in grazing cows offered sufficient forage to meet their prepartum energy requirements. The lack of effect of prepartum dietary NFC content on milk production is consistent with the general lack of effect of this treatment on blood metabolites and hormones postpartum.

A further conclusion that can be inferred from the current experiment is that prepartum NFC content does not affect the milk production response to postpartum NFC content. A high NFC diet prepartum has been reported to increase the number (Reynolds et al., 2004) and size of ruminal papillae (Dirksen et al., 1997) and thereby promote greater absorption of VFA postpartum. The development of ruminal papillae is induced by VFA (Dirksen et al., 1985, 1997). However, Sakata and Tamate $(1978,1979)$ reported that this development is most influenced by ruminal butyrate production, and not by acetate or propionate. Ruminal butyrate production is less affected by carbohydrate type and more by energy intake. Because energy intake was not different between the prepartum treatments in the current study, the expectation is that papillae development would not have been different between PreP and PreC cows. This conclusion is consistent with that of Andersen et al. (1999), who reported that diets more representative of those offered during the prepartum period in the current study did not have meaningful effects on epithelial development. Although the introduction of a high NFC diet prepartum would acclimate the rumen microbial population to a high NFC diet postpartum (Overton and Waldron, 2004), data from the current study imply that this acclimation (up to $5 \mathrm{~kg}$ of concentrate DM) can be undertaken successfully in the first few days postpartum, particularly when feeding is computercontrolled in the milking parlor.

Some milk components were affected by postpartum diet irrespective of prepartum dietary NFC content. However, 4\% FCM and ECM were not affected by postpartum treatment, consistent with an isoenergetic intake and no difference in BCS loss. Cows offered a diet with greater NFC content postpartum produced less milk fat and more milk protein, and tended to produce more milk lactose. The reduced milk fat content and yield is consistent with other grazing studies in which cows were supplemented with concentrate (Bargo et al., 2003; Roche et al., 2006). Reduced milk fat production due to dietary changes was originally attributed to changes in the concentration and ratio of rumen VFA, and, because of this, a reduced supply of milk fat precursors (acetate and butyrate). Subsequent research, however, did not support the reduced lipogenic precursor hypotheses (see review by Bauman and Griinari, 2001). Instead, it has been demonstrated that a dietinduced milk fat depression is due primarily to alterations in rumen biohydrogenation pathways, resulting in unique fatty acid intermediates (e.g., trans-10, cis-12 conjugated linoleic acid) that are potent inhibitors of milk fat synthesis (Bauman and Griinari, 2001). The actual biohydrogenation intermediate(s) responsible for reduced milk fat synthesis in pasture-fed dairy cows is not known.

The increased protein yield in cows offered a high NFC diet postpartum is probably a reflection of the greater milk yield ( $\mathrm{kg}$ of milk/cow per $\mathrm{d}$ ) in these cows, because milk protein concentration was not affected by treatment. The lack of an effect on milk protein concen- 

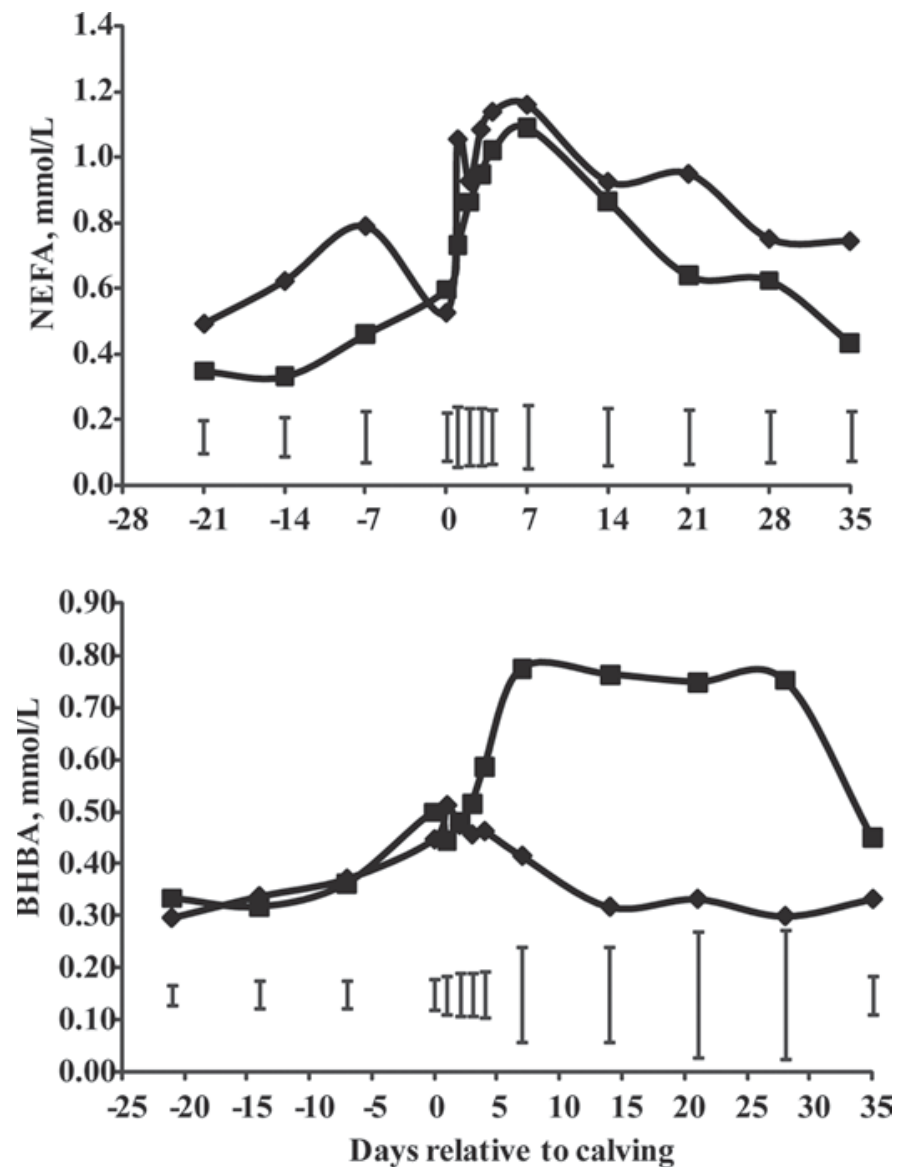

Figure 3. Plasma NEFA and BHBA concentrations of cows offered isoenergetic diets differing in NFC concentration pre- and postpartum. Treatment diets contained either low (pasture and pasture silage; $\mathbf{\square})$ or high (pasture, pasture silage, and a grain-based concentrate; $\bullet$ ) NFC concentrations. Vertical bars represent twice the standard error of the difference.

tration is consistent with Carruthers et al. (1997), who reported no effect of dietary NFC content on milk protein concentration or microbial protein synthesis when cows consumed isoenergetic diets. They inferred from their results that the type of available carbohydrate or degradation rate of carbohydrate was not limiting microbial synthesis on high-quality spring pasture and that it was fermentable energy intake, rather than type of fermentable energy, that regulated microbial protein synthesis. However, it is possible that the lack of effect in both studies reflects a lack of statistical power to detect the small differences in milk protein expected from dietary changes. In general, there is a positive relationship between NFC intake and milk protein, with a 0.01-percentage-unit increase in milk protein with each $1 \mathrm{~kg}$ of DM increase in concentrate DMI (Bargo et al., 2003; Roche et al., 2006). This response is identical to the numerical increase in milk protein percentage in the high NFC cows postpartum. Further research is required to separate the milk protein effect of NFC from that of increased energy intake.

The tendency for an increase in milk lactose yield in PostC cows in the current study is likely a result of an increase in circulating glucose. Glucose is the sole precursor for the glucose and galactose moieties of lactose, and facilitative glucose transport is upregulated between several fold and several hundred fold during the transition from late pregnancy to early lactation (Zhao and Keating, 2007). As lactose is the major osmoregulator of milk yield, the availability of glucose for increased lactose production also explains the tendency $(P=0.07$; Figure 1$)$ for increased milk yield in cows consuming a postpartum diet with greater NFC content. The increasing treatment difference in blood glucose concentrations from d 7 to 28 and the associated increasing difference in milk yield are consistent with this premise.

\section{Modeling the Diet Using the Cornell Net Protein and Carbohydrate System}

The effect of the imposed diets pre- and postpartum on the ruminal fermentation of carbohydrate and protein, and the amount of metabolizable protein reaching the small intestine could not be determined from the current experimental design. However, it was possible to model the effect of diet on energy and protein balance using the Cornell Net Protein and Carbohydrate System (CNCPS; Fox et al., 1992). Kolver et al. (1998) evaluated the CNCPS for pasture-based systems, and concluded that if effective fiber as a percentage of NDF, the fractional degradation rate of the fiber and protein fractions, and lignin as a percentage of NDF were modified to better reflect superior quality pastures, the CNCPS was effective at modeling microbial protein flows and blood urea nitrogen concentrations, thereby providing an effective means of predicting energy and protein balance in pasture-fed cows. Based on the assumptions of Kolver et al. (1998), effective fiber as a percentage of NDF, the fractional degradation rate of the B3 fraction of fiber and B2 fraction of protein, and lignin as a percentage of NDF were estimated to be $40 \%, 13.5 \%, 22 \%$, and 3.5 .

The CNCPS-predicted diet composition (including $\mathrm{ME})$ was very similar to the reported composition presented in Table 1, confirming the appropriateness of the CNCPS for modeling pasture-based diets following adjustment of key fiber and fiber degradation characteristics (Kolver et al., 1998). The CNCPS predicted that PreP cows had 143 and $132 \%$ of predicted ME and MP requirements, respectively, and that PreC cows had 143 and $125 \%$ of $\mathrm{ME}$ and MP requirements, respectively. The simulations confirm the isoenergetic nature of the 
Table 3. Plasma urea $(\mathrm{mmol} / \mathrm{L})$, albumin $(\mathrm{g} / \mathrm{L})$, and glucose $(\mathrm{mmol} / \mathrm{L})$ concentrations in cows offered pre- $($ PreC and PreP) and postpartum isoenergetic diets (PostC and PostP) differing in the ratio of structural to nonfiber carbohydrate content ${ }^{1}$

\begin{tabular}{|c|c|c|c|c|c|c|c|c|c|c|c|c|c|}
\hline \multirow[b]{2}{*}{ Item } & \multicolumn{13}{|c|}{ Day relative to calving } \\
\hline & -21 & -14 & -7 & 0 & 1 & 2 & 3 & 4 & 7 & 14 & 21 & 28 & 35 \\
\hline PreC & 3.78 & 3.80 & 3.74 & 4.84 & 4.17 & 3.05 & 3.35 & 3.31 & 3.09 & 3.20 & 3.13 & 3.25 & 3.41 \\
\hline PreP & 4.94 & 4.93 & 4.77 & 6.41 & 4.91 & 3.63 & 3.46 & 3.84 & 3.66 & 3.29 & 3.12 & 3.21 & 3.73 \\
\hline PostC & & & & & 4.74 & 3.05 & 2.74 & 2.91 & 2.64 & 2.41 & 2.53 & 2.39 & 2.79 \\
\hline PostP & & & & & 4.34 & 3.63 & 4.07 & 4.23 & 4.11 & 4.08 & 3.72 & 4.07 & 4.34 \\
\hline Prepartum & $<0.001$ & $<0.001$ & $<0.001$ & $<0.001$ & $<0.05$ & $<0.05$ & 0.63 & $<0.05$ & $<0.01$ & 0.65 & 0.94 & 0.85 & 0.20 \\
\hline Postpartum & & & & & 0.19 & $<0.011$ & $<0.001$ & $<0.001$ & $<0.001$ & $<0.001$ & $<0.001$ & $<0.001$ & $<0.001$ \\
\hline Pre $\times$ Post & & & & & 0.68 & 0.42 & 0.73 & 0.91 & 0.83 & 0.74 & 0.41 & 0.34 & 0.42 \\
\hline \multicolumn{14}{|l|}{ Albumin } \\
\hline PreC & 34.0 & 34.2 & 34.2 & 34.3 & 33.2 & 32.5 & 32.5 & 32.5 & 32.5 & 33.3 & 34.24 & 34.48 & 34.17 \\
\hline PreP & 34.8 & 35.3 & 35.3 & 35.9 & 35.5 & 34.5 & 33.9 & 34.7 & 35.1 & 35.0 & 34.94 & 35.52 & 35.27 \\
\hline PostC & & & & & 34.5 & 33.9 & 33.8 & 33.8 & 33.8 & 34.0 & 34.39 & 34.25 & 33.99 \\
\hline Pre $\times$ Post & & & & & 0.94 & 0.60 & 0.73 & 0.84 & 0.61 & 0.46 & 0.20 & $<0.05$ & 0.55 \\
\hline \multicolumn{14}{|l|}{ Glucose } \\
\hline PreC & 3.50 & 3.48 & 3.58 & 4.04 & 3.60 & 3.48 & 3.39 & 3.28 & 3.11 & 3.18 & 3.26 & 3.37 & 3.43 \\
\hline PreP & 3.49 & 3.54 & 3.67 & 3.93 & 3.59 & 3.42 & 3.22 & 3.23 & 3.15 & 3.28 & 3.32 & 3.33 & 3.52 \\
\hline PostC & & & & & 3.56 & 3.43 & 3.38 & 3.30 & 3.23 & 3.37 & 3.44 & 3.52 & 3.52 \\
\hline PostP & & & & & 3.62 & 3.47 & 3.23 & 3.21 & 3.03 & 3.09 & 3.14 & 3.18 & 3.42 \\
\hline SED & 0.054 & 0.057 & 0.106 & 0.152 & 0.097 & 0.072 & 0.091 & 0.087 & 0.090 & 0.085 & 0.096 & 0.092 & 0.085 \\
\hline \multicolumn{14}{|l|}{$P$-value } \\
\hline Prepartum & 0.84 & 0.24 & 0.42 & 0.46 & 0.95 & 0.41 & 0.06 & 0.57 & 0.65 & 0.26 & 0.58 & 0.60 & 0.29 \\
\hline Postpartum & & & & & 0.53 & 0.55 & 0.10 & 0.29 & $<0.05$ & $<0.01$ & $<0.01$ & $<0.001$ & 0.23 \\
\hline Pre $\times$ Post & & & & & 0.48 & 0.39 & 0.75 & 0.36 & 0.09 & 0.95 & 0.57 & 0.62 & 0.87 \\
\hline
\end{tabular}

${ }^{1}$ Prepartum diets (114 MJ of ME consumed/cow per d) were pasture and pasture silage (PreP) or pasture and pasture silage supplemented with $3 \mathrm{~kg} \mathrm{DM} /$ cow per d of barley-corn grain concentrate (PreC). Postpartum diets (179 MJ of ME consumed/cow per d) were pasture and pasture silage (PostP) or pasture and pasture silage supplemented with $5 \mathrm{~kg} \mathrm{DM} /$ cow per d of barley-corn grain concentrate (PostC).

${ }^{2}$ Standard error of the difference.

diet, although the ME surplus for BCS or additional fetal gain was almost $100 \%$ greater than that estimated from Roche et al. (2005).

The CNCPS predicted that the PostP cows were receiving $99 \%$ of required $\mathrm{ME}, 103 \%$ of required $\mathrm{MP}$, and between 113 and $121 \%$ of the amino acids methionine, lysine, and histidine. At the point in time that the simulation reflects (approximately 28 to $32 \mathrm{DIM}$ ), BCS mobilization would be approaching zero (Roche et al., 2006) and one would expect predicted ME allowable to reflect measured milk production. As would be expected from dietary CP concentration (20.1\% DM), rumen availability of $\mathrm{N}$ was nonlimiting (peptides and ammonia were 375 and $168 \%$ of predicted requirements, respectively). In comparison, PostC cows had 104 and $97 \%$ of predicted ME and MP requirements, respectively, implying a shortage of MP for further milk production, but relatively balanced diets for the current level of milk production. Amino acid supply was nonlimiting.
In short, CNCPS predictions were consistent with recorded treatment effects and indicated sufficient ME and MP for presented levels of production. Further increases in milk production would be limited by ME and MP in PostP and PostC, respectively.

\section{BCS, BW, and Indicators of Metabolic State}

The lack of a treatment effect on BCS and BW change pre- and postpartum is evidence of the isoenergetic nature of the diets; nonetheless, it was a surprising result. Physiologically, a high NFC diet and an associated increase in ruminal propionate production would be expected to elicit an increase in circulating insulin and an increase in hepatic and adipose GH receptor (GHR) abundance (Butler et al., 2003; Rhoads et al., 2004). The expected consequence would be an earlier recoupling of the somatotropic axis and an earlier return to a positive energy balance in PostC cows. However, although plasma glucose concentrations were greater in 
Table 4. Plasma growth hormone (GH, ng/mL), IGF-1 $(\mathrm{ng} / \mathrm{mL})$, and insulin $(\mu \mathrm{U} / \mathrm{mL})$ concentrations in cows offered pre- (PreC and PreP) and postpartum isoenergetic diets (PostC and PostP) differing in the ratio of structural to nonfiber carbohydrate content ${ }^{1}$

\begin{tabular}{|c|c|c|c|c|c|c|c|c|c|c|c|c|c|}
\hline \multirow[b]{2}{*}{ Item } & \multicolumn{13}{|c|}{ Day relative to calving } \\
\hline & -21 & -14 & -7 & 0 & 1 & 2 & 3 & 4 & 7 & 14 & 21 & 28 & 35 \\
\hline PreC & 1.65 & 1.64 & 2.32 & 6.59 & 4.02 & 2.57 & 2.78 & 2.85 & 2.84 & 3.08 & 3.66 & 4.09 & 3.83 \\
\hline PreP & 1.85 & 1.94 & 2.24 & 6.52 & 3.87 & 3.96 & 3.82 & 3.99 & 4.39 & 3.91 & 3.90 & 4.14 & 4.16 \\
\hline PostC & & & & & 3.54 & 3.39 & 3.10 & 3.24 & 3.45 & 3.50 & 3.55 & 4.26 & 3.49 \\
\hline PostP & & & & & 4.35 & 3.14 & 3.51 & 3.60 & 3.79 & 3.49 & 4.01 & 3.97 & 4.50 \\
\hline Prepartum & 0.35 & 0.23 & 0.83 & 0.96 & 0.82 & $<0.01$ & $<0.05$ & $<0.05$ & $<0.05$ & 0.17 & 0.69 & 0.93 & 0.58 \\
\hline Postpartum & & & & & 0.23 & 0.61 & 0.43 & 0.48 & 0.62 & 0.99 & 0.45 & 0.66 & 0.10 \\
\hline Pre $\times$ Post & & & & & 0.33 & 0.32 & 0.96 & 0.84 & 0.96 & 0.93 & 0.53 & 0.55 & 0.97 \\
\hline \multicolumn{14}{|l|}{ IGF-1 } \\
\hline PreC & 26.2 & 20.2 & 18.5 & 11.6 & 11.1 & 9.6 & 9.2 & 8.6 & 9.8 & 9.9 & 10.8 & 10.3 & 10.3 \\
\hline PreP & 30.2 & 24.1 & 21.7 & 9.6 & 9.7 & 9.6 & 9.1 & 8.8 & 8.8 & 8.4 & 9.5 & 9.2 & 11.2 \\
\hline PostC & & & & & 10.7 & 10.9 & 10.2 & 9.5 & 9.5 & 10.5 & 11.6 & 11.1 & 12.4 \\
\hline Pre $\times$ Post & & & & & 0.69 & 0.77 & 0.75 & 0.48 & 0.35 & 0.51 & 0.92 & 0.54 & 0.11 \\
\hline \multicolumn{14}{|l|}{ Insulin } \\
\hline PreC & 2.30 & 2.50 & 2.28 & 3.79 & 2.56 & 2.34 & 1.80 & 1.65 & 1.60 & 1.60 & 1.73 & 1.77 & 1.91 \\
\hline PreP & 2.91 & 2.95 & 3.16 & 3.31 & 2.10 & 1.83 & 1.58 & 1.47 & 1.49 & 1.63 & 1.68 & 1.72 & 1.92 \\
\hline PostC & & & & & 2.14 & 2.04 & 1.67 & 1.46 & 1.48 & 1.58 & 1.65 & 1.67 & 1.89 \\
\hline PostP & & & & & 2.52 & 2.13 & 1.71 & 1.67 & 1.60 & 1.65 & 1.75 & 1.82 & 1.95 \\
\hline SED & 0.265 & 0.288 & 0.285 & 0.398 & 0.250 & 0.228 & 0.157 & 0.139 & 0.141 & 0.136 & 0.140 & 0.134 & 0.148 \\
\hline \multicolumn{14}{|l|}{$P$-value } \\
\hline Prepartum & $<0.05$ & 0.12 & $<0.01$ & 0.24 & 0.07 & $<0.05$ & 0.16 & 0.19 & 0.47 & 0.81 & 0.73 & 0.74 & 0.95 \\
\hline Postpartum & & & & & 0.13 & 0.68 & 0.81 & 0.14 & 0.38 & 0.59 & 0.47 & 0.25 & 0.69 \\
\hline Pre $\times$ Post & & & & & 0.13 & 0.23 & $<0.05$ & 0.15 & 0.15 & 0.34 & 0.62 & $<0.05$ & 0.10 \\
\hline
\end{tabular}

${ }^{1}$ Prepartum diets (114 MJ of ME consumed/cow per d) were pasture and pasture silage (PreP) or pasture and pasture silage supplemented with $3 \mathrm{~kg} \mathrm{DM} /$ cow per d of barley-corn grain concentrate (PreC). Postpartum diets (179 MJ of ME consumed/cow per d) were pasture and pasture silage (PostP) or pasture and pasture silage supplemented with $5 \mathrm{~kg} \mathrm{DM} /$ cow per d of barley-corn grain concentrate (PostC).

${ }^{2}$ Standard error of the difference.

the PostC cows, presumably a result of the increased propionate provided for gluconeogenesis, there was no consistent effect of postpartum diet on plasma insulin concentration. However, this may merely be an effect of one blood sample per week masking the effect of treatment on insulin. In support of this hypothesis, diet altered plasma IGF-1 concentration (a more temporally stable hormone than insulin), with PostC cows having 20 to $25 \%$ greater circulating concentrations from 14 DIM. Although results did not indicate a treatment effect on circulating GH concentrations, the IGF-1 results imply an increased transcript abundance of hepatic IGF-1 and, probably, GHR-1A in those cows consuming the high NFC diet postpartum. An earlier recoupling of the somatotropic axis is indicated by this observation. Consistent with this, Roche et al. (2009b) reported that concentrate supplementation increased GHR-1A and IGF-1 mRNA expression by wk 4 postpartum. However, they did not have an earlier measure of transcript abundance to determine when this recou- pling occurred. Consistent with the results presented here and the gene expression results reported by Roche et al. (2009b), Roche et al. (2006) reported no effect of concentrate supplementation (up to $6 \mathrm{~kg}$ of DM/ cow per d) on the rate of loss of BCS or BW to $6 \mathrm{wk}$ postpartum, but concentrate supplementation linearly reduced DIM to nadir BCS and BW (i.e., the duration of negative energy balance), thereby increasing nadir BCS. Similarly, Pedernera et al. (2008) reported a similar decrease in BCS and BW postpartum in cows fed to achieve 6,748 or $8,746 \mathrm{~L}$ of milk/305-d. These data imply a failure of diet to influence the rate of BCS loss in early lactation, even when energy intake is increased. However, the BCS phenotype presented by Roche et al. (2006), in conjunction with diet effects on the transcript abundance of GHR and IGF-1 in liver tissue (Fenwick et al., 2008; Roche et al., 2009b), implies that supplementation with NFC will reduce the period of negative energy balance and increase circulating concentrations of IGF-1 earlier than cows not receiving supplementary 
Table 5. Plasma calcium and magnesium concentrations $(\mathrm{mmol} / \mathrm{L})$ in cows offered pre- (PreC and PreP) and postpartum isoenergetic diets (PostC and PostP) differing in the ratio of structural to nonfiber carbohydrate content ${ }^{1}$

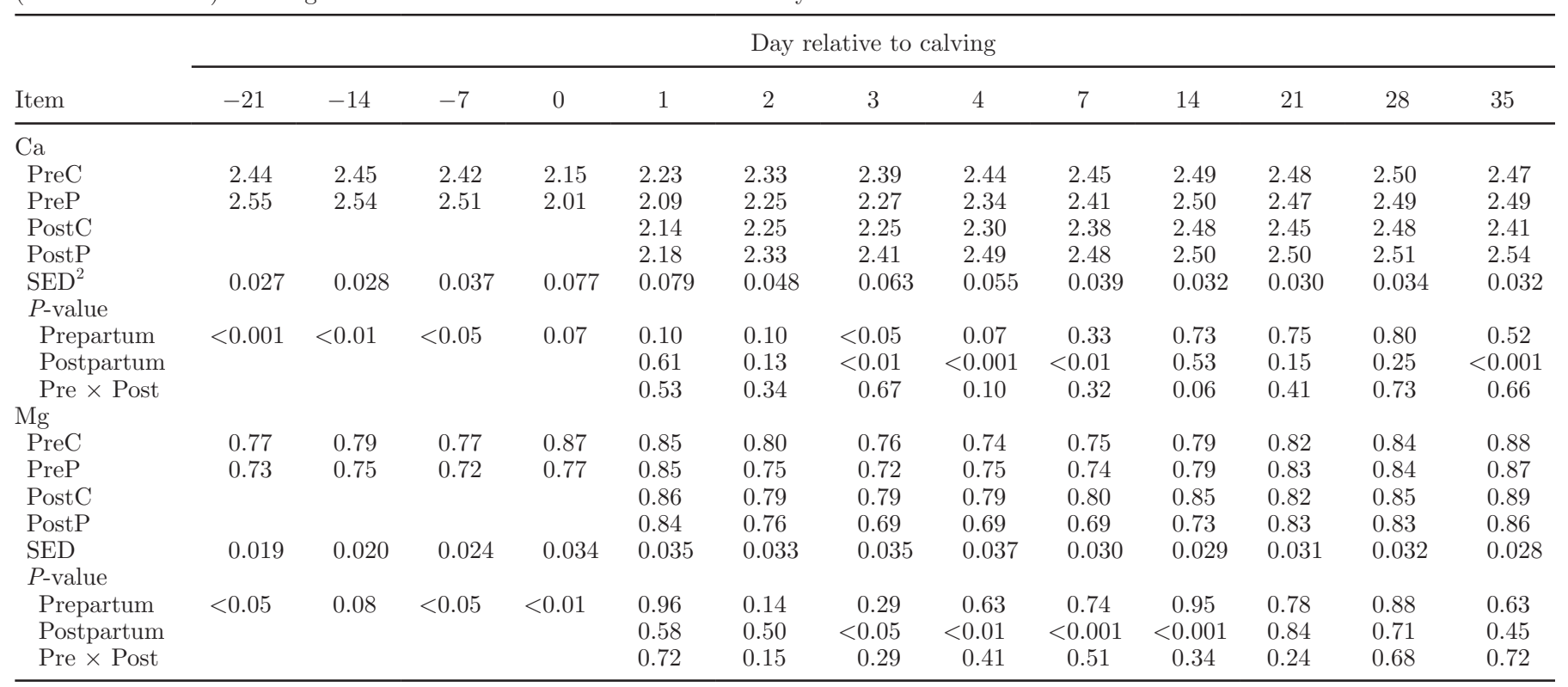

${ }^{1}$ Prepartum diets (114 MJ of ME consumed/cow per d) were pasture and pasture silage (PreP) or pasture and pasture silage supplemented with $3 \mathrm{~kg} \mathrm{DM} /$ cow per d of barley-corn grain concentrate (PreC). Postpartum diets (179 MJ of ME consumed/cow per d) were pasture and pasture silage (PostP) or pasture and pasture silage supplemented with $5 \mathrm{~kg} \mathrm{DM} /$ cow per d of barley-corn grain concentrate (PostC).

${ }^{2}$ Standard error of the difference.

NFC in pasture diets. The increased plasma glucose and IGF-1 concentrations in PostC cows in the present study indicate that the somatotropic recoupling effects of NFC supplementation in these studies may be related, at least in part, to carbohydrate type rather than supplementary energy per se. The contribution of insulin to the recoupling of the axis (Butler et al., 2003; Rhoads et al., 2004) would support this hypothesis. More detailed studies are required on hepatic and adipose gene expression differences and protein production in cows fed isoenergetic diets differing in their structural to NFC ratio to understand the role of energy and carbohydrate type in these processes.

The apparent paradox between NEFA and BHBA profiles in the current study is notable. The lack of treatment effect on BCS and BW change postpartum is largely consistent with the general lack of effect in plasma NEFA concentrations. However, circulating BHBA concentrations were consistently double in PostP cows compared with PostC cows. This discrepancy between 2 widely used indicators of energy status was previously highlighted by Roche et al. (2002), where early lactation Holstein-Friesian cows offered either pasture or a TMR diet presented no difference in BCS loss or plasma NEFA concentrations, but cows offered pasture had greater circulating concentrations of BHBA. Although not reported as such, Wylie et al. (2008) noted that NEFA concentrations decline postprandially, whereas
BHBA concentrations increase, highlighting the lack of a consistent effect of treatment on these metabolites. Further support comes from Bertics et al. (1992), where, although liver triglyceride levels were reduced in cows that were force-fed, plasma BHBA concentrations increased. These results are important because BHBA is often used as an indicator of energy balance, with one recent publication (Pedernera et al., 2008) suggesting that changes in BCS do not well reflect changes in energy balance because they did not concur with circulating concentrations of BHBA.

The inverse association between propionate and ketogenesis is long known, with Schultz et al. (1949) and Van Soest and Allen (1959) reporting reductions in blood ketone bodies with propionate supplementation. The effect of propionate on blood ketone body concentration was further confirmed by Corse and Elliott (1970), with propionate infusions reducing the concentration of circulating ketone bodies in early lactation; however, this relationship was not evident during the dry period (consistent with results presented here) or in late lactation, implying that the inverse association may hold only when the animal is in negative energy balance. Propionate, therefore, does not have a direct effect on ketogenesis. The indirect effect of propionate on ketogenesis has been postulated to be a result of competition for oxaloacetate between gluconeogenesis and fatty acid oxidation - the significant demand for 
glucose in the "modern" dairy cow resulting in reduced availability of oxaloacetate for fatty acid oxidation, thereby resulting in ketone body accumulation. However, this hypothesis is no longer supported by the known biochemistry of these two processes (Drackley et al., 2001). The likely increase in ruminal propionate production from the greater intake of NFC could, however, affect hepatic ketogenesis in other ways. For example, the intra-mitochondrial activity of 3-hydroxy3 -methylglutaryl-CoA synthase, which is a regulatory step in the conversion of acetyl-Co A to ketone bodies, is regulated by propionate, potentially preventing the accumulation of ketone bodies, and propionate has also been reported to be an inhibitor of $\beta$-oxidation (Drackley et al., 2001). It is also plausible that the lack of propionate in the PostP cows increased the circulating concentration of BHBA, rather than the greater production of propionate in PostC cows reducing circulating ketone bodies. Drackley et al. (2001) succinctly summarized the requirement for ketogenesis in non-propionate-derived gluconeogenesis (i.e., gluconeogenesis from alanine and pyruvate). Irrespective of the mechanism, these data acknowledge the reduction in the risk of ketosis with increasing content of NFC in the postpartum diet, but also highlight the fact that BHBA is not an effective indicator of energy balance, and certainly not one sufficiently sensitive for comparing energy balance in different dietary treatments.

\section{CONCLUSIONS}

The NFC content of the prepartum diet offered to dairy cows altered plasma metabolite and hormone concentrations, but had no effect on subsequent BCS or milk production characteristics. In contrast, milk and milk protein yields were increased by a greater dietary NFC content postpartum, but milk fat yield declined by almost $60 \%$ more than the increase in milk protein. These effects did not follow an improved energy balance, but probably reflect an effect of dietary carbohydrate type on rumen fermentation and hepatic gluconeogenesis, and resulting effects on plasma glucose, and mammary glucose uptake and lactose synthesis. The data do not imply a metabolic or production advantage to altering precalving dietary SC to NFC concentrations, and only limited benefit to altering this ratio postcalving.

\section{ACKNOWLEDGMENTS}

This study was funded by the DairyNZ Inc. (Hamilton, New Zealand) and the Foundation for Research, Science and Technology through contracts DRCX0204 and DRCX0301. The authors are grateful for the sup- port from Dairy NZ colleagues: technical support of P. W. Aspin, the managerial support of B. Sugar and A. Napper, and all the help afforded them by Lye Dairy Farm staff; the statistical support of B. Dow is also gratefully acknowledged.

\section{REFERENCES}

Agenäs, S., E. Burstedt, and K. Holtenius. 2003. Effects of feeding intensity during the dry period. 1. Feed intake and milk production. J. Dairy Sci. 86:870-882.

Andersen, J. B., J. Sehested, and K. L. Ingvartsen. 1999. Effect of dry cow feeding strategy on rumen $\mathrm{pH}$, concentration of volatile fatty acids, and rumen epithelium development. Acta Agric. Scand. A Anim. Sci. 49:149-155.

Barbano, D. M., J. M. Lynch, and J. R. Fleming. 1991. Direct and indirect determination of true protein content of milk by Kjeldahl analysis: Collaborative study. J. Assoc. Off. Anal. Chem. 74:281288.

Bargo, F., L. D. Muller, E. S. Kolver, and J. E. Delahoy. 2003. Invited review: Production and digestion of supplemented dairy cows on pasture. J. Dairy Sci. 86:1-42.

Bauman, D. E., and J. M. Griinari. 2001. Regulation and nutritional manipulation of milk fat: Low-fat milk syndrome. Livest. Prod. Sci. 70:15-29.

Bell, A. W. 1995. Regulation of organic nutrient metabolism during transition from late pregnancy to early lactation. J. Anim. Sci. 73:2804-2819.

Bertics, S. J., R. R. Grummer, C. Cadorniga-Valino, and E. E. Stoddard. 1992. Effect of prepartum dry matter intake on liver triglyceride concentration and early lactation. J. Dairy Sci. 75:1914-1922.

Butler, S. T., A. L. Marr, S. H. Pelton, R. P. Radcliff, M. C. Lucy, and W. R. Butler. 2003. Insulin restores GH responsiveness during lactation-induced negative energy balance in dairy cattle: effects of expression of IGF-1 and GH receptor 1A. J. Endocrinol. 176:205217.

Carruthers, V. R., P. G. Neil, and D. E. Dalley. 1997. Effect of altering the non-structural: Structural carbohydrate ratio in a pasture diet on milk production and ruminal metabolites in cows in early and late lactation. Anim. Sci. 64:393-402.

Corse, D. A., and J. M. Elliott. 1970. Propionate utilization by pregnant, lactating, and spontaneously ketotic dairy cows. J. Dairy Sci. 53:740-746.

Corson, D. G., G. C. Waghorn, M. J. Ulyatt, and J. Lee. 1999. Forage analysis and livestock feeding. Proc. NZ Grassl. Assoc. 61:127132.

Dirksen, G., S. Dori, A. Arbel, M. Schwartz, and H. G. Liebich. 1997. The rumen mucosa-Its importance as a metabolic organ of the high producing dairy cow. Israel J. Vet. Med. 52:73-79.

Dirksen, G., H. Liebich, and K. Mayer. 1985. Adaptive changes of the ruminal mucosa and functional and clinical significance. Bovine Pract. 20:116-120.

Douglas, G. N., J. K. Drackley, T. R. Overton, and H. G. Bateman. 1998. Lipid metabolism and production by Holstein cows fed control or high fat diets at restricted or ad libitum intakes during the dry period. J. Dairy Sci. 81(Suppl. 1):295. (Abstr.)

Dowman, M., and F. Collins. 1982. The use of enzymes to predict the digestibility of animal feeds. J. Sci. Food Agric. 33:689-696.

Downing, J. A., J. Joss, P. Connel, and R. J. Scaramuzzi. 1995. Ovulation rate and the concentration of gonadotrophic and metabolic hormones in ewes fed lupin grain. J. Reprod. Fertil. 103:137-145.

Drackley, J. K. 1999. ADSA Foundation Scholar Award. Biology of dairy cows during the transition period: The final frontier? J. Dairy Sci. 82:2259-2273.

Drackley, J. K., T. R. Overton, and G. N. Douglas. 2001. Adaptations of glucose and long-chain fatty acid metabolism in liver of dairy cows during the periparturient period. J. Dairy Sci. 84(E Suppl.):E100-E112. 
Fenwick, M. A., R. Fitzpatrick, D. A. Kenny, M. G. Diskin, J. Patton, J. J. Murphy, and D. C. Wathes. 2008. Interrelationships between negative energy balance (NEB) and IGF regulation in liver of lactating dairy cows. Domest. Anim. Endocrinol. 34:31-44.

Fox, D. G., C. J. Sniffen, J. D. O'Connor, J. B. Russell, and P. J. Van Soest. 1992. A net carbohydrate and protein system for evaluating cattle diets: 3. Cattle requirements and diet adequacy. J. Anim. Sci. 70:3578-3596.

Gluckman, P. D., J. J. Johnson-Barrett, J. H. Butler, B. W. Edgar, and T. R. Gunn. 1983. Studies on insulin-like growth factor-I and -II by specific radioligand assays in umbilical cord blood. Clin. Endocrinol. (Oxf.) 19:405-413.

Godden, S. M., S. C. Stewart, J. F. Fetrow, P. Rapnicki, R. Cady, W. Weiland, H. Spencer, and S. W. Eicker. 2003. The relationship between herd rbST-supplementation and other factors and risk for removal for cows in Minnesota Holstein dairy herds. Pages 55-64 in Proc. Four-State Nutr. Conf., LaCrosse, WI. Publication MWPS-4SD16. MidWest Plan Service, Ames, IA.

Grummer, R. R. 1995. Impact of changes in organic nutrient metabolism on feeding the transition dairy cow. J. Anim. Sci. 73:2820-2833.

Hales, C. N., and P. J. Randle. 1963. Immunoassay of insulin with insulin-antibody precipitate. Biochem. J. 88:137-146.

Holcomb, C. S., H. H. Van Horn, H. H. Head, M. B. Hall, and C. J. Wilcox. 2001. Effects of prepartum dry matter intake and forage percentage on postpartum performance of lactating dairy cows. J. Dairy Sci. 84:2051-2058.

International Dairy Federation. 1987. Milk: Determination of fat content-Röse Gottlieb gravimetric method (reference method) in IDF Standard FIL-IDF. Vol. 1C. IDF, Brussels, Belgium.

Keady, T. W. J., C. S. Mayne, D. A. Fitzpatrick, and M. A. McCoy. 2001. Effect of concentrate feed level in late gestation on subsequent milk yield, milk composition and fertility in dairy cows. J. Dairy Sci. 84:1468-1479.

Kolver, E. S., L. D. Muller, M. C. Barry, and J. W. Penno. 1998. Evaluation and application of the Cornell net carbohydrate and protein system for dairy cows fed diets based on pasture. J. Dairy Sci. 81:2029-2039.

McNamara, S., F. P. O'Mara, M. Rath, and J. J. Murphy. 2003. Effects of different transition diets on dry matter intake, milk production, and milk composition in dairy cows. J. Dairy Sci. 86:2397-2408.

Overton, T. R., and M. R. Waldron. 2004. Nutritional management of transition dairy cows: Strategies to optimize metabolic health. J. Dairy Sci. 87(E. Suppl.):E105-E119.

Payne, R. W., S. A. Harding, D. A. Murray, D. M. Soutar, D. B. Baird, A. I. Glaser, I. C. Channing, S. J. Welham, A. R. Gilmour, R. Thompson, and R. Webster. 2008. GenStat release 11 reference manual, part 2 directives. VSN International, Hemel Hempstead, Hertfordshire, UK.

Pedernera, M., S. C. García, A. Horagadoga, I. Barchia, and W. J. Fulkerson. 2008. Energy balance and reproduction on dairy cows fed to achieve low or high milk production on a pasture-based system. J. Dairy Sci. 91:3896-3907.

Reynolds, C. K., B. Durst, B. Lupoli, D. J. Humphries, and D. E. Beever. 2004. Visceral tissue mass and rumen volume in dairy cows during the transition from late gestation to early lactation. J. Dairy Sci. 87:961-971.

Reynolds, L. P., C. L. Ferrell, D. A. Robertson, and S. P. Ford. 1986. Metabolism of the gravid uterus, foetus and utero-placenta at several stages of gestation in cows. J. Agric. Sci. 106:437-444.

Rhoads, R. P., J. W. Kim, B. J. Leury, L. H. Baumgard, N. Segoale, S. J. Frank, D. E. Bauman, and Y. R. Boisclair. 2004. Insulin increases the abundance of the growth hormone receptor in liver and adipose tissue of periparturient dairy cows. J. Nutr. 134:1020-1027.

Roche, J. R. 2007. Milk production responses to pre- and postcalving dry matter intake in grazing dairy cows. Livest. Sci. 110:12-24.
Roche, J. R., D. P. Berry, and E. S. Kolver. 2006. Holstein-Friesian strain and feed effects on milk production, body weight, and body condition score profiles in grazing dairy cows. J. Dairy Sci. 89:3532-3543.

Roche, J. R., C. R. Burke, J. K. Kay, C. V. C. Phyn, S. Meier, and M. C. Lucy. 2009b. Genetic strain x diet interactions on physiological parameters associated with milk production, energy partitioning, and reproduction. Ruminant physiology: Digestion, metabolism, and effects of nutrition on reproduction and welfare. Proc. XI Int Symp. Rum. Physiol. 776-777.

Roche, J. R., P. Dillon, S. Crosse, and M. Rath. 1996. The effect of closing date of pasture in autumn and turnout date in spring on sward characteristics, dry matter yield and milk production of spring-calving dairy cows. Ir. J. Agric. Food Res. 35:127-140.

Roche, J. R., P. G. Dillon, C. R. Stockdale, L. H. Baumgard, and M. J. VanBaale. 2004. Relationships among international body condition scoring systems. J. Dairy Sci. 87:3076-3079.

Roche, J. R., E. S. Kolver, and J. K. Kay. 2005. Influence of precalving feed allowance on periparturient metabolic and hormonal responses and milk production in grazing dairy cows. J. Dairy Sci. 88:677689.

Roche, J. R., E. S. Kolver, and A. Napper. 2002. Pasture versus total mixed ration during the periparturient period. Proc. N.Z. Soc. Anim. Prod. 62:252-256.

Roche, J. R., L. R. Turner, J. M. Lee, D. C. Edmeades, D. J. Donaghy, K. A. Macdonald, J. W. Penno, and D. P. Berry. 2009a. Weather, herbage quality and milk production in pastoral systems. 2 . Temporal patterns and intra-relationships in herbage quality and mineral concentration parameters. Anim. Prod. Sci. 49:200-210.

Roughan, G. P., and R. Holland. 1977. Predicting in vivo digestibilities of herbage by exhaustive enzymatic hydrolysis of cell walls. J. Sci. Food Agric. 28:1057-1064.

Sakata, T., and H. Tamate. 1978. Rumen epithelial cell proliferation accelerated by rapid increase in intraruminal butyrate. J. Dairy Sci. 61:1109-1113.

Sakata, T., and H. Tamate. 1979. Rumen epithelial cell proliferation accelerated by proprionate and acetate. J. Dairy Sci. 62:49-52.

Schultz, L. H., V. R. Smith, and H. A. Lardy. 1949. The effect of the administration of various fatty acids on the blood ketone levels of ruminants. J. Dairy Sci. 32:817-822.

Smith, K. L., M. R. Waldron, J. K. Drackley, M. T. Socha, and T. R. Overton. 2005. Performance of dairy cows as affected by prepartum dietary carbohydrate source and supplementation with chromium throughout the transition period. J. Dairy Sci. 88:255-263.

Tyrrell, H. F., and J. T. Reid. 1965. Prediction of the energy value of cow's milk. J. Dairy Sci. 48:1215-1223.

Van Soest, P. J., and N. N. Allen. 1959. Studies on the relationships between rumen acids and fat metabolism of ruminants fed on restricted roughage diets. J. Dairy Sci. 42:1977-1985.

Verbyla, A. P., B. R. Cullis, M. G. Kenward, and S. J. Welham. 1999. The analysis of designed experiments and longitudinal data by using smoothing splines (with discussion). Appl. Stat. 48:269311.

Wildman, E. E., G. M. Jones, P. E. Wagner, R. L. Boman, H. F. Troutt, and T. N. Lesch. 1982. A dairy cow body condition scoring system and its relationship to selected production characteristics. J. Dairy Sci. 65:495-501.

Wylie, A. R. G., S. Woods, A. F. Carson, and M. McCoy. 2008. Peripheral changes in metabolites and metabolic hormone concentrations in high-genetic-merit dairy heifers and their relationship to energy balance in early lactation. J. Dairy Sci. 91:577-586.

Zhao, F.-Q., and A. F. Keating. 2007. Expression and regulation of glucose transporters in the bovine mammary gland. J. Dairy Sci. 90(E. Suppl.):E76-E86. 